“C 2019 IEEE. Personal use of this material is permitted. Permission from IEEE must be obtained for all other uses, in any current or future media, including reprinting/republishing this material for advertising or promotional purposes, creating new collective works, for resale or redistribution to servers or lists, or reuse of any copyrighted component of this work in other works." 


\title{
The Technical, Operational and Energy Policy Issues for Developing Photovoltaic Systems: A Review
}

\author{
Ibrahim Anwar Ibrahim, Member, IEEE, and M. J. Hossain, Senior Member, IEEE \\ School of Engineering, Faculty of Science and Engineering \\ Macquarie University \\ NSW 2109, Australia \\ ibrahim.a.ibrahim@hdr.mq.edu.au, jahangir.hossain@mq.edu.au
}

\begin{abstract}
In recent years, photovoltaic (PV) units are getting popular in different countries, including Australia, as they contribute to reducing emissions of $\mathrm{CO}$ and enhancing energy efficiency. However, several technical and economic challenges need to be addressed to ensure maximum benefit from this renewable generation. Moreover, the development of energy policies and regulations also affects the development of such systems. Therefore, this paper aims to review several technical, operational and energy policy issues for developing reliable and efficient PV systems. In addition, this paper summarizes the existing modeling and sizing methods, the maximum power point tracking (MPPT) techniques, and the interface power-electronic devices in this field. Moreover, recommendations for future researchers and investors for developing such systems are provided in this research paper.
\end{abstract}

Keywords-PV systems, energy policy, MPPT, PV technical issues, PV operational issues.

\section{INTRODUCTION}

Recently, the use of renewable energy sources has been rapidly growing worldwide. At the same time, the fossil fuel is running out and the global warming problem is sharply increasing. Based on that, future energy generation will greatly depend on using of the renewable energy sources for reducing the global warming problem [1]. Also, the renewable energy sources have some precarious problems in their production because of their intermittent nature [2]. A photovoltaic (PV) energy source is one of the most promising renewable energy sources for generating electricity [3]. The development of this technology is still emerging in terms of increasing its efficiency and decreasing its cost. The levelized cost of electricity (LCoE), which is generated by PV systems, is cost-effective in world markets across residential and commercial segments. Several energy policies and regulations around the world have encouraged investors to invest in such systems. In 2010, the capacity of PV projects has been larger than that in the previous four decades. In 2013, around $100 \mathrm{MW}$ capacity was installed per day to meet the growing load demand. Moreover, $85 \mathrm{GW}$ PV capacity was in place worldwide in 2017. Based on the IEA road-map 2014 edition, the capacity of installed PV systems is estimated to be $16 \%$ of the generation of global electricity by 2050 . To meet this target, the technical, operational and energy policy issues have to be taken into consideration for developing PV systems to increase their usage in the global market [4].

PV systems can be categorized in the form of feeding the load demand as standalone PV systems and gridconnected PV systems [5]. They are used for supplying several loads, for example water pumping systems, residential and commercial appliances, street lighting, telecommunications, electrical vehicles, military, and agricultural applications. In general, PV systems may be centralized or decentralized. Around $60 \%$ of PV systems are installed as decentralized, while $40 \%$ of PV systems are centralized systems. PV systems now contribute only $1 \%$ of the global market [2]. Existing review papers focused only technical aspect in developing PV systems [6] and [7]. However, several other important aspects are missing, which help the designer, the investor and the end user to understand the requirements to get reliable, and cost-effective PV system. These aspects are energy policies and regulations, optimal modeling and sizing techniques of PV systems, the proper interfacing power-electronic devices, and the important operational issues.

This paper aims to summarize the technical, operational and energy policy issues for developing PV systems and increasing their usage worldwide. The structure of this review paper is as follows: Section II classifies the types of PV systems. Section III highlights the energy policy issues for increasing investment on PV systems. Section IV reviews different modeling and sizing techniques of PV systems. Section V briefly highlights the maximum-power-point tracking techniques and interfacing power-electronic devices for increasing the efficiency of PV systems. Section VI describes some of the important operational issues. Section VII summarizes some recommendations based on the reviewed research works. Finally, Section VIII concludes the paper.

\section{TyPES OF PV SYSTEMS}

In general, PV systems can be categorized in terms of their use to three types; standalone PV systems, hybrid PV systems, and grid-connected PV systems [8]. This 
classification relies upon the PV systems operational and component configurations. The PV systems are designed to provide AC and/or DC power, and connected with or without storage energy systems. Moreover, PV system have the capability to connect with other renewable energy sources [9].

Standalone PV systems aim to provide the electrical energy in both DC and/or AC form to the required loads. Mostly, such a system is used to operate in remote areas where it is independent of the electric utility grid. This system can be operated solely by a PV array, or by a PV/battery combination. The typical standalone PV system consists of a PV array, storage energy system, DC/DC converter, charge controller and inverter. Usually, a maximum-power-point tracker (MPPT) is used to operate the system at its maximum efficiency [10].

Grid-connected PV systems convert solar radiation into electrical power and then inject it directly to the grid. Mostly, this system is used without a back-up energy storage system. In this case, the system needs less maintenance and has lower cost. The inverter is the main component in this type of system, which converts the DC power generated by the PV array into an AC power consistent according to the voltage level and the power quality requirements of the electrical power system. The back-up energy storage system is mostly utilized in grid-connected PV systems for providing power during fluctuations, supplying electricity during peak hours, improving power quality and operating reserves [11].

Hybrid PV systems may be operated as a gridconnected system or a standalone system. In this system, two types or more of renewable energy sources cooperate to cover the load demand such as PV/wind, $\mathrm{PV} /$ diesel generator, $\mathrm{PV} /$ wind /diesel generator etc. [12].

\section{ENERGy Policy Issues}

Currently, the most challenging issue is to deal with negative impacts of fossil fuel sources. Therefore, the current energy policies aim to reduce these negative impacts on the environment by supporting renewable energy initiatives for meeting the daily energy demand. In 2012, most initiatives for using and developing the PV systems applications have been in Europe. Recently, these initiatives are dramatically increasing in Asia, especially in China. The major concern in the existing PV technology is its low energy efficiency and high capital costs. As a result, new energy policies are required for renewing proposals, system integration and regulatory issues in order to increase the use of PV systems in both residential and commercial use.

In [13], the authors mentioned the existing energy policies for PV systems in several countries such as USA, China, Germany, Australia, Japan, Canada and France, and highlighted the required regulations for integrating renewable energy sources into the electrical grid. Moreover, it is mentioned that the retail financing terms must be flexible to grow PV technology in the market and for the end user. Several policies in different forms of economic incentives are reviewed which need to be improved to increase the use of such PV systems. These economic policies include feed-in-tariffs (FIT), production incentives, renewable portfolio standard (RPS), investment tax credits, quota requirements, pricing laws, trading systems etc. The main motivation of improving these policies is to reduce the negative impacts of the energy sector on the environment, reduce reliance on fossil fuels and encourage development in this field for both industrial and residential sectors. Based on that, Table I summarizes some of the energy policy issues in developing PV systems. In addition, Table II shows the forecast capacity of PV projects (GWp) and the cost of the energy generated (US cents $/ \mathrm{kWh}$ ) for United States of America (USA), Europe, China and Japan.

TABLE I

ENERGy POLICY ISSUES IN PV SYSTEMS

\begin{tabular}{|l|l|l|}
\hline $\begin{array}{l}\text { Objectives of the energy } \\
\text { policy }\end{array}$ & $\begin{array}{l}\text { The methodology of the } \\
\text { energy policy }\end{array}$ & Ref. \\
\hline $\begin{array}{l}\text { Study the impacts of PV - } \\
\text { based distribution genera- } \\
\text { tion (DG) system on eco- } \\
\text { nomic and environmental } \\
\text { issues }\end{array}$ & $\begin{array}{l}\text { The use of PV-based DG } \\
\text { systems aims to decrease } \\
\text { the volatility in wholesale } \\
\text { prices and decrease the cost } \\
\text { of the centralized PV plant } \\
\text { on a long-term investment }\end{array}$ & [14] \\
\hline $\begin{array}{l}\text { Study the initiatives for } \\
\text { decentralized PV systems }\end{array}$ & $\begin{array}{l}\text { Enhancing the energy effi- } \\
\text { ciency in distribution sys- } \\
\text { tems to encourage the use of } \\
\text { renewable sources }\end{array}$ & [15] \\
\hline $\begin{array}{l}\text { Study the cost benefit of } \\
\text { the PV system deploy- } \\
\text { ment }\end{array}$ & $\begin{array}{l}\text { An hourly PV energy output } \\
\text { of net feed-in-tariff (FIT) } \\
\text { values }\end{array}$ & {$[16]$} \\
\hline Design a FIT program & $\begin{array}{l}\text { A guaranteed internal rate } \\
\text { of return (IRR) value that } \\
\text { encourages investments } \\
\text { based on several FIT values }\end{array}$ & [17] \\
\hline $\begin{array}{l}\text { Detailed methodology for } \\
\text { energy allocation based on } \\
\text { a multi-objective model }\end{array}$ & $\begin{array}{l}\text { A tool model for assist- } \\
\text { ing designers and investors } \\
\text { in matters related to energy } \\
\text { policy }\end{array}$ & [18] \\
\hline
\end{tabular}

From Table I, it is noticed that the investment and finance issues are essential to improve the energy policies. Therefore, credible and clear decisions from the policy makers aim at decreasing the level of risks, and inspiring confidence. This will encourage investors and consumers for increasing installation of PV projects.

TABLE II

The Forecast CAPACITY OF PV PROJECTS (GWP) AND THE COST OF THE ENERGY GENERATED (US CENTS/KWH) [19]

\begin{tabular}{|l|l|l|l|l|l|l|}
\hline \multirow{2}{*}{ Year } & \multicolumn{2}{|c|}{2010} & \multicolumn{2}{c|}{2020} & \multicolumn{2}{c|}{2030} \\
\cline { 2 - 7 } & Capacity & Cost & Capacity & Cost & Capacity & Cost \\
\hline USA & 2.1 & 13.4 & 36 & 10 & 246 & 7 \\
\hline Europe & 3.0 & 19.8 & 41 & 11 & 200 & 6.6 \\
\hline China & 0.37 & 25.9 & 63.5 & 9.4 & 634 & 5 \\
\hline Japan & 4.8 & 20.6 & 30 & 12.5 & 205 & 8.6 \\
\hline World & 14.0 & & 200 & & 1805 & \\
\hline
\end{tabular}

Based on Table II, it is clear that the installation of PV systems has risen worldwide with an average rate of $49 \%$ per annum. Based on recent trends, it is expected that the share of the PV systems will rise in China from $18 \%$ of global generation in 2015 to $40 \%$ in 2030, while the price of insulation of PV systems will decrease by 
$81 \%$ in 2030. In Asian countries, it is expected that the share of PV systems will increase to be $25 \%$ in 2030. In Japan, the expected share of PV systems will increase by $97 \%$ from 2010 to 2030 , while the price of installation of PV systems will decrease by $58 \%$ by 2030. In USA, the expected share of PV systems may settle at around 15\% from 2020 to 2030, while the price of the installation of PV systems will decrease by $48 \%$ by 2030 . In Europe, the expected share of PV systems will decline linearly from $44 \%$ in 2015 to $4 \%$ in 2030, while the price of the installation of PV systems will decrease by $67 \%$ by 2030 . As a result, in 2030, the highest share of PV systems will be in China, with the lowest price.

On the other hand, developing countries are currently increasing the implementation of PV systems in order to sustain their economic growth parallel with reaching their environmental goals. In fact, the installation of PV systems in these countries increased by $38 \%$ (291 GW) of global PV capacity in 2016 compared to $5 \%$ (6 GW) in 2006 [20]. According to the medium-term renewableenergy market report, published by the International Energy Agency (IEA) in 2016, developing countries will lead the future installation of PV systems by 540 GW in 2021 [21]. This capacity represents nearly the half of the global installations. Developing countries create some policies for encouraging stakeholders to invest in PV systems with competitive and sustainable prices. Currently, the low cost of investing in PV systems installation creates new opportunities for investors to shift their investments to the power sector, since solar energy is widely available. In 2015 to 2016, prices of LCoE in small-scale PV projects were less than $0.10 \$ / \mathrm{kWh}$ in South Africa, India, Brazil etc. and less than $0.04 \$ / \mathrm{kWh}$ in Chile, Mexico, and the UAE [22]. Recently, large-scale PV projects have been rapidly installed to meet the increased load demand of growing economies in developing countries. The largescale PV projects are very important for developing countries for three main reasons. First, the distribution of solar radiation is very good in most developing countries [23]. Second, the manufacturing costs of PV technologies are decreased by nearly $74 \%$ in 2016 [24]. Third, the installation period for PV plants is relatively short compared with other power generation plants such as hydropower plants [25]. TABLE III highlights some information about the installation of PV projects in developing countries such as the name of the plan, its implementation period, its capacity, its capital cost and its LCoE.

Based on TABLE III, several plans for installing PV systems starting in 2016 and to the present in developing countries such as India, the UAE, Jordan, South Africa, Zambia, Uganda, Jamaica, Brazil, Chile and El Salvador. The prices for LCoE vary in the range of 0.024 to $0.184 \$ / \mathrm{kWh}$. From TABLE I, it can be concluded as follows: First, 27 PV projects are expected to be executed, from $6 \mathrm{MW}$ in India to $800 \mathrm{MW}$ in Dubai. Second, the capital costs of such projects are within the range of $7.5 \$ \mathrm{mn}$ to $600 \$ \mathrm{mn}$, while the average capital cost is $97.48 \$ \mathrm{mn}$ which indicates
TABLE III

A SUMMARY OF THE INSTALLATION OF PV PROJECTS IN DEVELOPING COUNTRIES [26]

\begin{tabular}{|c|c|c|c|c|c|}
\hline Country & plan & $\begin{array}{l}\text { Execute } \\
\text { time }\end{array}$ & $\begin{array}{l}\text { Capacity } \\
\text { (MW) }\end{array}$ & $\begin{array}{l}\text { Capital } \\
\text { cost } \\
(\$ m n)\end{array}$ & $\begin{array}{l}\text { LCoE } \\
(\$ / \mathbf{k W h})\end{array}$ \\
\hline \multirow[t]{5}{*}{ India } & $\begin{array}{l}\text { Karnataka } \\
\text { (Phase II) }\end{array}$ & $\begin{array}{l}2013- \\
2015\end{array}$ & 6 & 7.5 & 0.11 \\
\hline & $\begin{array}{l}\text { Andhra } \\
\text { Pradesh }\end{array}$ & $\begin{array}{l}2014- \\
2016\end{array}$ & 40 & 36 & 0.086 \\
\hline & Telangana & $\begin{array}{l}2014- \\
2016\end{array}$ & 10 & 10 & 0.108 \\
\hline & $\begin{array}{l}\text { JNNSM } \\
\text { (Phase II } \\
\text { - Batch I) }\end{array}$ & $\begin{array}{l}2014- \\
2015\end{array}$ & 20 & 18 & 0.088 \\
\hline & Punjab & $\begin{array}{l}2015- \\
2016\end{array}$ & 28 & 25.2 & 0.116 \\
\hline \multirow[t]{2}{*}{ UAE } & $\begin{array}{l}\text { Dubai } \\
\text { (Phase II) }\end{array}$ & $\begin{array}{l}2014- \\
2017\end{array}$ & 200 & 250 & 0.059 \\
\hline & $\begin{array}{l}\text { Dubai } \\
\text { (Phase } \\
\text { III) }\end{array}$ & $\begin{array}{l}2016- \\
2018\end{array}$ & 800 & 600 & 0.03 \\
\hline \multirow[t]{4}{*}{ Jordan } & $\begin{array}{l}\text { Phase II, } \\
\text { P1 }\end{array}$ & $\begin{array}{l}2015- \\
2018\end{array}$ & 50 & 56.5 & 0.061 \\
\hline & $\begin{array}{l}\text { Phase II, } \\
\text { P2 }\end{array}$ & $\begin{array}{l}2015- \\
2018\end{array}$ & 50 & 56.5 & 0.065 \\
\hline & $\begin{array}{l}\text { Phase II, } \\
\text { P3 }\end{array}$ & $\begin{array}{l}2015- \\
2018\end{array}$ & 50 & 59 & 0.069 \\
\hline & $\begin{array}{l}\text { Phase II, } \\
\text { P4 }\end{array}$ & $\begin{array}{l}2015- \\
2018\end{array}$ & 50 & 60 & 0.077 \\
\hline \multirow[t]{6}{*}{$\begin{array}{l}\text { South } \\
\text { Africa }\end{array}$} & $\begin{array}{l}\text { REIPP } \\
\text { (R3-P1) }\end{array}$ & $\begin{array}{l}2013- \\
2016\end{array}$ & 75 & 183.75 & 0.085 \\
\hline & $\begin{array}{l}\text { REIPP } \\
\text { (R3-P2) }\end{array}$ & $\begin{array}{l}2013- \\
2016\end{array}$ & 75 & 202.5 & 0.097 \\
\hline & $\begin{array}{l}\text { REIPP } \\
\text { (R3-P3) }\end{array}$ & $\begin{array}{l}2013- \\
2016\end{array}$ & 75 & 202.5 & 0.109 \\
\hline & $\begin{array}{l}\text { REIPP } \\
(\mathrm{R} 4-\mathrm{P} 1)\end{array}$ & $\begin{array}{l}2015- \\
2018\end{array}$ & 75 & 93.75 & 0.064 \\
\hline & $\begin{array}{l}\text { REIPP } \\
\text { (R4-P2) }\end{array}$ & $\begin{array}{l}2015- \\
2017\end{array}$ & 75 & 93.75 & 0.066 \\
\hline & $\begin{array}{l}\text { REIPP } \\
\text { (R4-P3) }\end{array}$ & $\begin{array}{l}2015- \\
2018\end{array}$ & 75 & 93.75 & 0.069 \\
\hline \multirow[t]{2}{*}{ Zambia } & $\begin{array}{l}100 \text { MW } \\
\text { Solar-P1 }\end{array}$ & $\begin{array}{l}2016- \\
2017\end{array}$ & 45 & 49.5 & 6 \\
\hline & $\begin{array}{l}100 \quad \text { MW } \\
\text { Solar-P2 }\end{array}$ & $\begin{array}{l}2016- \\
2017\end{array}$ & 28 & 40.04 & 0.078 \\
\hline Uganda & Get FiT & $\begin{array}{l}2014- \\
2016\end{array}$ & 10 & 19 & 0.164 \\
\hline Jamaica & $\begin{array}{ll}37 & \text { MW } \\
\text { RE } & \end{array}$ & $\begin{array}{l}2016- \\
2018\end{array}$ & 33 & 48.51 & 0.085 \\
\hline \multirow[t]{3}{*}{ Brazil } & Pernambucd & $\begin{array}{l}2013- \\
2015\end{array}$ & 11 & 18.04 & 0.103 \\
\hline & Plan VI & $\begin{array}{l}2014- \\
2017\end{array}$ & 260 & 319.8 & 0.087 \\
\hline & Plan VII & $\begin{array}{l}2015- \\
2017\end{array}$ & 75 & 92.25 & 0.085 \\
\hline \multirow[t]{2}{*}{ Chile } & $\begin{array}{l}2015 / 01 \\
\text { Plan }\end{array}$ & $\begin{array}{l}2016- \\
2021\end{array}$ & 100 & 59 & 0.20 \\
\hline & $\begin{array}{l}2015 / 02 \\
\text { Plan }\end{array}$ & $\begin{array}{l}2015- \\
2017\end{array}$ & 141 & 197.4 & 0.068 \\
\hline $\begin{array}{l}\text { El Sal- } \\
\text { vador }\end{array}$ & $\begin{array}{l}100 \text { MW } \\
\text { RE Plan }\end{array}$ & $\begin{array}{l}2014- \\
2016\end{array}$ & 100 & 150 & 0.102 \\
\hline
\end{tabular}

the availability of low capital cost for investment in large-scale PV plants in developing countries. Third, the $\mathrm{LCoE}$ varies between $0.03 \$ / \mathrm{kWh}$ in the UAE to $0.116 \$ / \mathrm{kWh}$ in India. It is clear that investments in PV systems increased during these years in developing countries, which will let these countries lead this field in the near future.

\section{Modeling And Sizing Techniques for PV SYSTEMS}

Optimum modeling of the components in PV systems may lead to improvements in the performance and operation of PV systems at minimum cost. This 
includes accurate modeling of the PV module, storage technology, power-electronic devices and loads as well. Table IV summarizes the modeling methods of different topologies of PV systems.

TABLE IV

MOdeling Methods For PV Systems

\begin{tabular}{|c|c|c|c|}
\hline $\begin{array}{l}\text { Type of } \\
\text { PV system }\end{array}$ & Objectives & $\begin{array}{l}\text { Results of the } \\
\text { study }\end{array}$ & Ref. \\
\hline \multirow[t]{2}{*}{$\begin{array}{l}\text { Standalone } \\
\text { PV system }\end{array}$} & $\begin{array}{l}\text { Study the } \\
\text { performance of } \\
\text { a standalone PV } \\
\text { system by modeling } \\
\text { the PV modules and } \\
\text { storage battery using } \\
\text { MATLAB }\end{array}$ & $\begin{array}{l}\text { Optimal design } \\
\text { and operation } \\
\text { of a standalone } \\
\text { PV system at a } \\
\text { minimum cost }\end{array}$ & [27] \\
\hline & $\begin{array}{l}\text { Sizing a standalone } \\
\text { PV system by mod- } \\
\text { eling the solar ra- } \\
\text { diation, load demand } \\
\text { and system efficiency } \\
\text { based on a developed } \\
\text { regression model }\end{array}$ & $\begin{array}{l}\text { The accuracy of } \\
\text { the predicted re- } \\
\text { sults match with } \\
\text { the actual dataset } \\
\text { with a confidence } \\
\text { level of } 92 \%\end{array}$ & [28] \\
\hline \multirow[t]{2}{*}{$\begin{array}{l}\text { Grid- } \\
\text { connected } \\
\text { PV system }\end{array}$} & $\begin{array}{l}\text { Modeling the grid- } \\
\text { connected PV sys- } \\
\text { tem components, PV } \\
\text { modules, MPPT, and } \\
\text { inverter and its syn- } \\
\text { chronization with the } \\
\text { grid) using MATLAB }\end{array}$ & $\begin{array}{l}\text { Developing a } \\
\text { proper method } \\
\text { for modeling } \\
\text { and controlling } \\
\text { a grid-connected } \\
\text { PV system }\end{array}$ & [29] \\
\hline & $\begin{array}{l}\text { Sizing a } \text { grid- } \\
\text { connected PV } \\
\text { for a pystem } \\
\text { application particular } \\
\text { Homer software }\end{array}$ & $\begin{array}{l}\text { Optimal size of } \\
\text { the components } \\
\text { of grid-connected } \\
\text { PV system at } \\
\text { a minimum net } \\
\text { present cost }\end{array}$ & [30] \\
\hline \multirow[t]{2}{*}{$\begin{array}{l}\text { Hybrid PV } \\
\text { system }\end{array}$} & $\begin{array}{l}\text { Sizing and energy } \\
\text { dispatch control of a } \\
\text { PV/battery/diesel } \\
\text { system using } \\
\text { RETScreen software }\end{array}$ & $\begin{array}{l}\text { Evaluation of } \\
\text { the energy } \\
\text { performance of } \\
\text { the system with } \\
\text { its economic } \\
\text { analysis }\end{array}$ & [31] \\
\hline & $\begin{array}{lr}\text { Sizing } & \text { the } \\
\text { components } & \text { of } \\
\text { a PV/wind system } \\
\text { using Homer software }\end{array}$ & $\begin{array}{l}\text { Sizing the } \\
\text { components of } \\
\text { the system for a } \\
\text { higher level of } \\
\text { availability at a } \\
\text { minimum cost }\end{array}$ & [32] \\
\hline
\end{tabular}

Based on Table IV, it is noted that to obtain optimum results of the sizing for PV systems, the following issues must be taken into account:

- small step historical meteorological and load demand time-series data (hourly or smaller);

- accurate techniques for modeling the components of the PV systems;

- a well-formulated objective function; and

- a fast and accurate simulation algorithm.

\section{MAXIMUM-POWER-POINT TRACKING TeChniques AND InTERFACE POWER-EleCtronic DEVICES}

The output power of a PV module fluctuates because of the variations in the solar radiation and the ambient temperature. Here, the power delivered to the load side fluctuates, and may affect the performance of the load. Moreover, the load demand varies from time to time and will move the operating point on the currentvoltage PV curve. To solve this issue, a maximumpower-point tracker (MPPT) is used for ensuring the maximum system efficiency. Several MPPT techniques are used to extract the required amount of current to operate the system at its maximum-power point. Table $\mathrm{V}$ summarizes different studies of MPPT techniques for PV systems.

TABLE V

MPPT TECHNIQUES FOR PV SYSTEMS

\begin{tabular}{|c|c|c|}
\hline MPPT techniques & Results of the study & Ref. \\
\hline $\begin{array}{lr}\text { Perturb } & \text { and } \\
\text { observe } & \text { (PO) } \\
\text { and incremental } \\
\text { conductance } & \text { (IC) } \\
\text { methods }\end{array}$ & $\begin{array}{l}\text { Improving the efficiency of a grid- } \\
\text { connected PV system based on } \\
\text { a variable-step algorithm with a } \\
\text { buck-boost converter }\end{array}$ & [33] \\
\hline $\begin{array}{l}\text { Fuzzy logic control } \\
\text { (FLC) method }\end{array}$ & $\begin{array}{l}\text { Developed an adaptive FL con- } \\
\text { troller for controlling the MOSFET } \\
\text { on/off time in a boost converter and } \\
\text { developed an MPPT under differ- } \\
\text { ent conditions }\end{array}$ & {$[34]$} \\
\hline $\begin{array}{l}\text { Offline and online } \\
\text { methods }\end{array}$ & $\begin{array}{l}\text { Analyzed the performance and } \\
\text { tracker efficiency of a PV system } \\
\text { in both steady-state and dynamic } \\
\text { behavior }\end{array}$ & {$[35]$} \\
\hline $\begin{array}{l}\text { Converterless } \\
\text { matching } \\
\text { technique }\end{array}$ & $\begin{array}{l}\text { Explored the advantages of using } \\
\text { the MPPT in PV systems based on } \\
\text { linear and resistive loads with real } \\
\text { test conditions }\end{array}$ & [36] \\
\hline \begin{tabular}{ll}
\multicolumn{2}{l}{ Voltage-controlled } \\
MPPT and level- \\
shifted & PWM \\
modulation &
\end{tabular} & $\begin{array}{l}\text { Developed an MPPT algorithm for } \\
\text { charging and discharging a battery } \\
\text { by tracking the PV output voltage. } \\
\text { This study aims to improve the effi- } \\
\text { ciency and reliability of the battery } \\
\text { with an optimal life-cycle }\end{array}$ & {$[37]$} \\
\hline
\end{tabular}

Based on Table V, several MPPT techniques have been utilized for maximizing the efficiency of PV systems. The choice of proper technique will be done based on the type of application, system requirements, implementation of the hardware, cost, simplicity, and effectiveness.

In several applications, the voltage level generated by the PV modules must be in a specific range to operate the inverter. Buck and boost converters are used to adjust the output voltage to be in that range. The buck converter aims to step down the voltage level, while the boost converter aims to step up that level. The relationship between the input and the output voltage level in such devices and their design formulas are mentioned in [38]. Table VI summarizes the impact of using power-electronic interface devices in PV systems.

According to Table VI, the selection of the proper converter for a particular PV system application is a critical role, which affects the efficiency of the such system. Several power-electronic interface devices are implemented, which aims to reduce the mismatch losses, and to increase the efficiency and reliability of the PV system as well.

\section{PV PLANT'S OPERATIONAL ISSUES}

To validate the modeling and sizing techniques as well as get recommendations from the existing systems for developing future projects, the performance and reliability of the installed PV systems must be analyzed. In addition, an economic evaluation for the capital, maintenance and operation costs is supposed to be performed to determine the cost of the energy generated by the system. Therefore, several operational issues in PV plants are summarized in Table VII. 
TABLE VI

The Power-Electronic InTERface Devices IN PV Systems

\begin{tabular}{|l|l|l|}
\hline $\begin{array}{l}\text { Interface power- } \\
\text { electronic techniques }\end{array}$ & Results of the study & Ref. \\
\hline $\begin{array}{l}\text { Explore the principle of } \\
\text { work for the converter } \\
\text { and the control devices } \\
\text { in grid-connected PV sys- } \\
\text { tems }\end{array}$ & $\begin{array}{l}\text { The response speed is good } \\
\text { with lower oscillations }\end{array}$ & [11] \\
\hline $\begin{array}{l}\text { Describe the use of MPPT } \\
\text { with one-cycle control, } \\
\text { and the use of the power- } \\
\text { factor correction unit in a } \\
\text { grid-connected PV system }\end{array}$ & $\begin{array}{l}\text { An efficient operation for } \\
\text { the one-cycle control in } \\
\text { trom of power extracted }\end{array}$ & [39] \\
\hline $\begin{array}{l}\text { Study the performance of } \\
\text { a single-stage inverter }\end{array}$ & $\begin{array}{l}\text { Increased the quality of the } \\
\text { AC output power and the } \\
\text { operation of the MPPT }\end{array}$ & [40] \\
\hline $\begin{array}{l}\text { Study the energy losses by } \\
\text { the mismatch and propose } \\
\text { reduction techniques }\end{array}$ & $\begin{array}{l}\text { Decreased the effect of mis- } \\
\text { match losses in both par- } \\
\text { tial and homogeneous con- } \\
\text { ditions }\end{array}$ & [41] \\
\hline $\begin{array}{l}\text { Compare the performance } \\
\text { of using string and micro } \\
\text { inverters in PV systems }\end{array}$ & $\begin{array}{l}\text { Summarized advantages and } \\
\text { disadvantages of utilizing } \\
\text { string and micro inverters in } \\
\text { PV system based on differ- } \\
\text { ent technical and economic } \\
\text { indicators }\end{array}$ & [42] \\
\hline $\begin{array}{l}\text { Modeling and operating a } \\
\text { PV micro-inverter to study } \\
\text { its performance }\end{array}$ & $\begin{array}{l}\text { A developed inverter archi- } \\
\text { tecture with two switches } \\
\text { for controlling the inverter }\end{array}$ & [43] \\
\hline
\end{tabular}

\section{RECOMMENDATIONS}

From the previous research works, some recommendations are concluded. These recommendations can be summarized as follows:

- The updated proposals from the leading PV systems countries in the field of technology, system integration, legislative and regulatory issues will help to overcome the economic and non-economic barriers.

- Policymakers should facilitate the investments in PV projects more and more in developing countries to meet the load demand within the technical aspects.

- Well-planned PV projects, supportive energy policies and proper regulations are key roles to achieve low prices and increase the investments for installing PV plants in developing countries.

- Artificial intelligence (AI) methods have several advantages over conventional methods to optimally size PV systems.

- The accuracy of the modeling techniques for modeling the components of the PV systems, considering all factors, is an essential requirement for an accurate PV sizing.

- Suitable power-electronic device and MPPT technique are required to manage and control the power flow based on the variation of the load demand in order to improve the operation of the PV system.

- A feasible design of a PV system needs an accurate monitoring system which can be used for recording the important data about the status of the PV system for better protection and control as well as improving the performance and cost of future designs of PV plants.
TABLE VII

PV PLANT'S OPERATIONAL ISSUES

\begin{tabular}{|l|l|c|}
\hline Objectives & Results of the study & Ref. \\
\hline $\begin{array}{l}\text { Study the per- } \\
\text { formance of 4.9 } \\
\& \text { 5 MW DC } \\
\text { PV plants }\end{array}$ & $\begin{array}{l}\text { Obtained the parameters for perfor- } \\
\text { mance and costs over 5 years operation } \\
\text { period }\end{array}$ & [44] \\
\hline $\begin{array}{l}\text { Estimate } \\
\text { the cost of } \\
\text { preventive } \\
\text { scheduling } \\
\text { maintenance }\end{array}$ & $\begin{array}{l}\text { Developed an optimization method for } \\
\text { a systems cost }\end{array}$ & [45] \\
\hline $\begin{array}{l}\text { Examine a } \\
\text { PV-powered } \\
\text { reverse plant }\end{array}$ & $\begin{array}{l}\text { Th using of a 3-phase induction motor } \\
\text { reflects more efficient results than the } \\
\text { using of a DC motor in a PV-powered } \\
\text { reverse plant, which reduces the con- } \\
\text { sumption of the electrical energy }\end{array}$ & [46] \\
\hline $\begin{array}{l}\text { Study the } \\
\text { impact of } \\
\text { using new } \\
\text { methodologies } \\
\text { and tools on } \\
\text { a PV grid- } \\
\text { connected } \\
\text { system }\end{array}$ & $\begin{array}{l}\text { Reduced the limitations for using the } \\
\text { of the electrical grid }\end{array}$ & [47] \\
\hline $\begin{array}{l}\text { Study the } \\
\text { stability of } \\
\text { the PV system } \\
\text { frequently }\end{array}$ & $\begin{array}{l}\text { Measured the abnormal conditions and } \\
\text { the matching with the grid code }\end{array}$ & [48] \\
\hline $\begin{array}{l}\text { Study } \\
\text { PV system } \\
\text { operation and } \\
\text { its maintenance } \\
\text { cost }\end{array}$ & $\begin{array}{l}\text { Measured the system downtime and the } \\
\text { possibilities for reducing the cost }\end{array}$ & [49] \\
\hline
\end{tabular}

\section{CONCLUSIONS}

This paper presents reviews of the technical, operational and energy policy issues that affect the development of PV systems worldwide. A historical study of the technologies of producing the PV cells is presented, mentioning the characteristics of each technology. As the energy policies and regulations affect investors decisions for investing in PV systems, some of the studies are summarized to explore these policies, and the future capacities and prices for PV systems worldwide. Additionally, the paper includes a summarized study of existing modeling and sizing studies for different types of PV systems. Moreover, several studies for developing the power-electronic devices in the PV system are investigated to increase its efficiency. Finally, PV plants operational issues are mentioned for monitoring their performance, which can be used to develop higher efficiency and lower cost PV plants. The main objective is to summarize the existing technical challenges and present recommendations for future research work in developing PV systems.

\section{REFERENCES}

[1] J. Prasanth Ram, T. Sudhakar Babu, and N. Rajasekar, A comprehensive review on solar PV maximum power point tracking techniques, Renew. Sustain. Energy Rev., vol. 67, pp. 826-847, 2017.

[2] T. Khatib, A. Mohamed, and K. Sopian, A review of solar energy modeling techniques, Renew. Sustain. Energy Rev., vol. 16, no. 5, pp. 28642869, 2012.

[3] M. Villalva, J. Gazoli, and E. Filho, Comprehensive Approach to Modeling and Simulation of Photovoltaic Arrays, IEEE Trans. Power Electron., vol. 24, no. 5, pp. 11981208, 2009.

[4] M. V. D. Hoeven, Technology roadmap: solar photovoltaic energy, Int. Energy Agency (IEA), 2015. 
[5] M. H. Nehrir, C. Wang, K. Strunz, H. Aki, R. Ramakumar, J. Bing, Z. Miao, and Z. Salameh, A Review of Hybrid Renewable I Alternative Energy Systems for Electric Power Generation: IEEE Trans. Sustain. Energy, vol. 2, no. 4, pp. 392403, 2011.

[6] A. H. Jaaz, H. A. Hasan, K. Sopian, M. H. Haji Ruslan and $\mathrm{H}$. Zaidi, Design and development of compound parabolic concentrating for photovoltaic solar collector: Review, Renew. Sustain. Energy Rev., vol. 76, pp. 11081121, 2017.

[7] P. G. Sampaio and M. O. Gonzlez, Photovoltaic solar energy: Conceptual framework, Renew. Sustain. Energy Rev., vol. 74 pp. 590601, 2017.

[8] T. Khatib and W. Elmenreich, Novel simplified hourly energy flow models for photovoltaic power systems, Energy Convers. Manag., vol. 79, pp. 441448, 2014.

[9] T. Khatib, I. A. Ibrahim, and A. Mohamed, A review on sizing methodologies of photovoltaic array and storage battery in a standalone photovoltaic system, Energy Convers. Manag., vol. 120, pp. 430448, Jul. 2016.

[10] A. Fragaki and T. Markvart, Stand-alone PV system design: Results using a new sizing approach, Renew. Energy, vol. 33, no. 1, pp. 162167, 2008.

[11] W. Luo and G. Han, The Algorithms Research of Maximum Power Point Tracking in Grid-Connected Photovoltaic Generation System, in 2009 Second International Symposium on Knowledge Acquisition and Modeling, 2009, pp. 7780.

[12] S. Upadhyay and M. P. Sharma, A review on configurations, control and sizing methodologies of hybrid energy systems, Renew. Sustain. Energy Rev., vol. 38, pp. 4763, Oct. 2014.

[13] S. M. Moosavian, N. A. Rahim, J. Selvaraj, and K. H. Solangi, Energy policy to promote photovoltaic generation, Renew. Sustain. Energy Rev., vol. 25, pp. 4458, 2013.

[14] W. E. Lilley, L. J. Reedman, L. D. Wagner, C. F. Alie, and A. R. Szatowd, An economic evaluation of the potential for distributed energy in Australia, Energy Policy, vol. 51, pp. 277289, 2012.

[15] K. Reinsberger and A. Posch, Bottom-up initiatives for photovoltaic: incentives and barriers, J. Sustain. Dev. Energy, Water Env. Syst., vol. 2, no. 2, pp. 108117, 2014.

[16] B. Lee, M. Trcka, and J. Hensen, Economic performance assessment of the deployment of rooftop photovoltaic systems for industrial halls, in 12th International IBPSA Conference, 2011.

[17] I. Das, K. Bhattacharya, and C. Canizares, Optimal incentive design to facilitate solar PV investments in Ontario, IEEE Power Energy Soc. Gen. Meet., pp. 16, 2012.

[18] A. F. Zobaa and R. C. Bansal, Handbook of Renewable Energy Technology. USA: World Scientific Publishing Co Pte Ltd, 2011.

[19] A. Poullikkas, Technology and market future prospects of photovoltaic systems, J. Energy, Environ. Econ., vol. 1, no. 4, pp. 617634, 2010.

[20] IRENA, Renewable Energy Statistics 2017, Abu Dhabi, UAE, 2017.

[21] IEA, Medium-Term Renewable Energy Market Report 2016, 2016.

[22] Z. Dobrotkova, P. Audinet, and G. Sargsyan, What Drives the Price of Solar Photovoltaic Electricity in Developing Countries?, Washington DC., 2017.

[23] Solargis, Global Horizontal Irradiation (GHI) Solar Map, 2016. [Online]. Available: http://solargis.com/assets/graphic/freemap/GHI/Solargis-World-GHI-solarresource-\%0Amap-en.png. [Accessed: 29-May-2018].

[24] BNEF, Q1 2017 PV Market Outlook, 2017.

[25] IFC, A Project Developers Guide to Utility-scale Solar Photovoltaic Power Plants, Washington D.C., 2015.

[26] Z. Dobrotkova, K. Surana, and P. Audinet, The price of solar energy: Comparing competitive auctions for utility-scale solar PV in developing countries, Energy Policy, vol. 118, no. March, pp. 133148,2018

[27] I. A. Ibrahim, T. Khatib, and A. Mohamed, Optimal sizing of a standalone photovoltaic system for remote housing electrification using numerical algorithm and improved system models, Energy, vol. 126, pp. 392403, May 2017.

[28] P. G. Nikhil and D. Subhakar, Approaches for developing a regression model for sizing a stand-alone photovoltaic system, IEEE Power Energy Mag., vol. 5, no. 1, pp. 250257, 2015.

[29] S. Faisal, Model of grid connected photovoltaic system using Matlab/Simulink., J. Electr. Electron. Eng., vol. 2, no. 2, pp. 4755,2011
[30] Z. Ahmed and S. Singh, Modelling and control of grid connected photovoltaic system: a review, Int. J. Emerg. Technol. Adv. Electron. Eng. Res., vol. 3, no. 3, pp. 4049, 2013.

[31] T. Hove and T. Tazvinga, A techno-economic model for optimizing component sizing and energy dispatch for PV-dieselbattery hybrid power systems., J. Energy South Afr., vol. 23, no. 4, pp. 1828, 2012.

[32] T. Kaur and Pooja, Optimal sizing of solar photovoltaic-wind hybrid system, Int. J. Innov. Res. Electr., Electron., Instrum. Control Eng., vol. 3, no. 1, pp. 99103, 2015.

[33] P. Mohanty, Role of Power Converters in Distributed Solar Power Generation, J. Autom. Control Eng., vol. 2, no. 1, pp. 3842,2014

[34] P. Kumar and K. Babu, Power-management strategies for a gridconnected PV-FC hybrid system by using fuzzy logic controller, Int. J. Mod. Eng. Res., vol. 2, no. 2, pp. 358364, 2012.

[35] A. Reza Reisi, M. Hassan Moradi, and S. Jamasb, Classification and comparison of maximum power point tracking techniques for photovoltaic system: A review, Renew. Sustain. Energy Rev., vol. 19 , pp. 433443, 2013.

[36] K. Ishaque and Z. Salam, A review of maximum power point tracking techniques of PV system for uniform insolation and partial shading condition, Renew. Sustain. Energy Rev., vol. 19, pp. $475488,2013$.

[37] N. Hatti, J. Phontip, and S. Nuilers, A new technique for standalone photovoltaic energy management system, in 2013 15th European Conference on Power Electronics and Applications (EPE), 2013, pp. 110.

[38] W. Xiao, N. Ozog, and W. Dunford, Topology study of photovoltaic maximum power point tracking, IEEE Trans. Ind. Electron., vol. 54, no. 3, pp. 16961704, 2007.

[39] N. Femia, D. Granozio, and G. Petrone, Optimized one-cycle control in photovoltaic grid connected applications, IEEE Trans. Aerosp. Electron. Syst., vol. 42, no. 3, pp. 954972, 2006.

[40] S. Jain and V. Agarwal, A Single-Stage Grid Connected Inverter Topology for Solar PV Systems With Maximum Power Point Tracking, IEEE Trans. Power Electron., vol. 22, no. 5, pp. 19281940, 2007.

[41] N. Agarwal and A. Agarwal, Mismatch losses in solar photovoltaic array and reduction techniques., Int. J. Electr. Instrum. Eng., vol. 4, no. 1, pp. 1619, 2014.

[42] J. Patel and P. Solanki, Comparative analysis of string inverter and micro inverter for solar based power system, Int. J. Adv. Res. Electr., Electron. Instrum. Eng., vol. 3, no. 4, pp. 85098012, 2014.

[43] G. Paul, S. Kannan, N. Johnson, and J. George, Modeling and analysis of PV microinverter, Int. J. Innov. Res. Electr., Electron., Instrum. Eng., vol. 2, no. 2, pp. 10551058, 2014.

[44] B. P. Rand, J. Genoe, P. Heremans, and J. Poortmans, Solar Cells Utilizing Small Molecular Weight Organic Semiconductors, Prog. Photovolt Res. Appl., vol. 15, no. February 2013, pp. 659676, 2015.

[45] S. P. Canto, M. Papadrakakis, and M. G. Karlaftis, A model for preventive maintenance scheduling of power plants minimizing cost, in International Conference on Engineering and Applied Sciences Optimization, 2014.

[46] P. C. M. De Carvalho, D. B. Riffel, C. Freire, and F. F. D. Montenegro, The Brazilian experience with a photovoltaic powered reverse osmosis plant, Prog. Photovoltaics Res. Appl., vol. 12 , no. 5 , pp. $373385,2004$.

[47] F. Katiraei and J. Aguero, Solar integration challenges, studies for utility-scale photovoltaic distributed generation, IEEE Power Energy Mag, vol. 4, no. 17, pp. 6271, 201

[48] U. Jahn and W. Nasse, Operational performance of gridconnected PV systems on buildings in Germany, Prog. Photovoltaics Res. Appl., vol. 12, no. 6, pp. 441448, 2004.

[49] N. Enbar and T. Key, Addressing Solar Photovoltaic Operations and Maintenance Challenges, a survey of current knowledge and practices, Electric Power Research Institute (EPRI) White Paper, 2010. 